\title{
Activation of nucleolar and extranucleolar RNA synthesis and changes in the ribosomal content of human embryos developing in vitro
}

\author{
J. Tesařík*†, V. Kopečnýł, M. Plachot§ and J. Mandelbaum§ \\ * Station Centrale de Physiologie Animale, 78350 Jouy-en-Josas, France; $\$$ Research Institute of \\ Animal Production, 25161 Prague, Czechoslovakia; §INSERM, U 173, Hopital Necker-Enfants \\ Malades, 149, Rue de Sèvres, 75730 Paris, France
}

\begin{abstract}
Summary. RNA synthetic activity of human 2-16-cell embryos developing in vitro was studied by $\left[{ }^{3} \mathrm{H}\right]$ uridine light-microscope autoradiography. Parallelly cut thin sections were examined in the electron microscope. The first extranucleolar RNA synthesis was detected in 4-cell embryos, but nucleoli were never labelled until the 3rd cleavage (6-8-cell embryos). In 6-cell embryos the nucleolar labelling was mostly confined to a narrow peripheral zone. In later cleavage stages most of the blastomeres showed intensive labelling of nucleoli and extranucleolar chromatin. However, rather low levels of extranucleolar RNA synthesis and the absence of nucleolar activity were often seen even in blastomeres of fully compacted morulae. The activation of nucleolar RNA synthesis entailed a noticeable increase in the number of ribosomes (estimated by electron microscope morphometry) that followed a marked drop during the period between the 2-cell and 8-cell stages. The results indicate that the concentration of ribosomes in the preovulatory oocyte is a major factor of its developmental potential.
\end{abstract}

\section{Introduction}

It is generally accepted that the very early development of the mammalian embryo after fertilization is fully controlled by an oocyte-derived developmental programme but, later on, the control of the differentiation processes is gradually taken over by the embryo itself (reviewed by Epstein, 1975; Johnson, 1981; Magnuson \& Epstein, 1981; Flach, Johnson, Braude, Taylor \& Bolton, 1982). The oocyte control of the early developmental processes of the zygote is effected by a supply of maternally inherited molecules amongst which various species of RNA play a crucial role. Activation of the embryonic RNA synthesis that is obviously a necessary prerequisite for the transition from oocyte to embryo control seems to take place at different cleavage stages, depending on the species. The beginning of poly (A) + RNA (presumably mRNA) synthesis in the mouse can be detected from the late 1-cell stage (Clegg \& Pikó, 1983) while rRNA begins to be synthesized no sooner than at the 2-cell stage (Knowland \& Graham, 1972; Clegg \& Pikó, 1982) when there is also biochemical evidence for an overall increase in the incorporation of RNA precursors (Woodland \& Graham, 1969; Knowland \& Graham, 1972; Clegg \& Pikó, 1977). By contrast, the start of embryonic rRNA synthesis seems to be delayed up to the morula stage in the rabbit (Manes, 1971) although rabbit embryos produce heterogeneous RNA from the 2-cell stage onwards (Cotton, Manes \& Hamkalo, 1980). Incorporation of $\left[{ }^{3} \mathrm{H}\right]$ uridine could not be detected by autoradiography until the 4-cell stage in the pig and until the late 8-cell stage in cattle (V. Kopečný, unpublished data).

† Present address: Nad plovárnou 25, 58601 Jihlava, Czechoslovakia. 
Knowledge of the developmental stage at which synthesis of different species of embryonic RNA is triggered is necessary for a correct interpretation of the physiological meaning of many changes taking place in early conceptuses but also earlier, in oocytes during growth and maturation. Moreover, these investigations may provide additional information relative to the evaluation of oocyte and embryo suitability for in-vitro fertilization (IVF) programmes. We therefore undertook the work reported in this study.

\section{Materials and Methods}

Embryos. The embryos used in this study were supernumerary conceptuses from an IVF programme. Methodological details concerning ovarian stimulation and the techniques of IVF and embryo culture have been published elsewhere (Plachot et al., 1985). Apparently healthy 4-8-cell embryos showing regular cleavage rates and lacking signs of fragmentation were removed from the cohort of cultured conceptuses $40-60 \mathrm{~h}$ after insemination in treatment cycles in which at least 4 other embryos were replaced into the patient's uterine cavity. The embryos selected for research purposes were either used immediately in labelling experiments (see below) or cultured for an additional $24-48 \mathrm{~h}$ in order to obtain the early morula stage. In the case of 2-cell embryos, the selection was made $24-36 \mathrm{~h}$ after insemination in treatment cycles in which normal fertilization and cleavage had taken place in more than 6 preovulatory oocytes. From a total number of 20 embryos, 4 were at the 2-cell stage, 4 at the 4-cell stage, 2 at the 6-cell stage, and 5 at the 8-cell and early morula (12-16-cell) stages, respectively.

RNA labelling and autoradiography. For RNA labelling embryos were incubated for $1 \mathrm{~h}$ in $\mathrm{B} 2$ medium (API System, Montalieu-Vercieu, France) supplemented with $200 \mu \mathrm{Ci}\left[{ }^{3} \mathrm{H}\right] \mathrm{uridine} / \mathrm{ml}$ (Commissariat à l'Energie Atomique, Gif-sur-Yvette, France; sp. act. $27 \mathrm{Ci} / \mathrm{mmol}$ ) at a temperature of $37^{\circ} \mathrm{C}$ under a gas mixture containing $90 \% \mathrm{~N}_{2}, 5 \% \mathrm{O}_{2}$, and $5 \% \mathrm{Co}_{2}$. After the incubation, the embryos were briefly washed in radiolabelled precursor-free medium and fixed with a solution containing $2.5 \%$ glutaraldehyde, $0.6 \%$ paraformaldehyde, and $0.1 \%$ cold uridine in $0.06 \mathrm{M}-$ cacodylate buffer ( $\mathrm{pH} \mathrm{7.2)}$ for $1 \mathrm{~h}$. Fixed specimens were then washed to remove unincorporated radioactivity in $0.125 \mathrm{M}$-cacodylate buffer containing $0.2 \mathrm{M}$-sucrose and $0.1 \%$ unlabelled uridine at $4^{\circ} \mathrm{C}$ for at least $20 \mathrm{~h}$ (Monneron \& Moulé, 1969). This step was followed by a second fixation using the osmium-ferricyanide method (McDonald, 1984), dehydration in a graded ethanol series, treatment with propylene oxide, and embedding in Epon 812. Serial 1- $\mu \mathrm{m}$ sections were cut on an Ultrotome III LKB ultramicrotome and examined unstained using phase-contrast microscopy. Sections showing at least one blastomere nucleolus were collected on microscope slides and coated with Ilford $\mathrm{K} \cdot 5$ nuclear liquid emulsion. The slides were exposed at $4^{\circ} \mathrm{C}$ for 4 weeks and then developed with D 19. The autoradiographs were stained with methylene blue and examined in a light microscope using oil immersion optics.

Electron microscopy. Silver-coloured sections were cut from the Epon-embedded embryos using an Ultrotome III LKB ultramicrotome equipped with a diamond knife. Thin sectioning was performed at all section planes where a nucleolus was found in the parallelly cut $1-\mu \mathrm{m}$ sections allocated to autoradiography. The sections were stained with uranyl acetate and lead citrate, and viewed in a Philips 300 electron microscope.

For the morphometric estimation of the number of ribosomes, randomly selected areas of blastomeres were photographed and printed at a final magnification of $\times 50000$. Ribosomes were counted in photographic prints of standard size and their number per unit area of the section was calculated. The equation, reported by Loud (1968) as simplified by Pikó and Clegg (1982) was

$$
\mathrm{N}_{\mathrm{v}}=\mathrm{N}_{\mathbf{a}} / \mathrm{t}
$$

where $\mathrm{N}_{\mathrm{a}}=$ number of ribosomal profiles per unit section area and $\mathrm{t}=$ section thickness, and was 
used to determine the number of ribosomes in unit volume of the embryo $\left(\mathrm{N}_{\mathrm{v}}^{-}\right)$. The total number of ribosomes per embryo was calculated on the basis of the approximations used by Pikó \& Clegg (1982), assuming that the thickness of silver sections is $75 \mathrm{~nm}$ and the volume of the embryo remains nearly constant from the 2-cell to the early morula stage. Based on these presumptions, a standard value of the embryo volume was used throughout the cleavage stages under study. This volume was derived from the average diameter of all embryos subjected to the morphometric examination. The diameter of individual embryos was determined as the greatest value obtained from measurements of the inner diameter of the zona pellucida in a series of $1-\mu \mathrm{m}$ sections through the equator, using an ocular micrometer in the light microscope. These measurements gave a mean \pm s.d. embryo diameter of $117 \pm 2 \cdot 8 \mu \mathrm{m}$, resulting in a fixed embryo volume of $838000 \mu \mathrm{m}^{3}$. This value was reduced by the factor of $10 \%$ corresponding to the fraction of the intrazonal volume occupied by cell fragments and extracellular spaces.

This corrected standard embryo volume $\left(750000 \mu \mathrm{m}^{3}\right)$ was used for calculating the total number of ribosomes at all cleavage stages studied. Ribosomes were counted in at least 4 embryos of each stage (at least 2000 ribosomes per embryo). The concentrations of ribosomes in 8-cell embryos and early morulae were expressed separately for blastomeres possessing differentiated nucleoli incorporating $\left[{ }^{3} \mathrm{H}\right]$ uridine $(\mathrm{Nu}+$ blastomeres) and for those with functionally inactive nucleolus-like bodies (Tesaŕík et al., 1987) lacking RNA synthetic activity ( $\mathrm{Nu}-$ blastomeres). The statistical significance of the differences in the ribosomal counts between cleavage stages was analysed by using the Wilcoxon's test.

\section{Results}

\section{RNA synthesis}

The first detectable incorporation of $\left[{ }^{3} \mathrm{H}\right]$ uridine into human embryos cleaving in vitro appeared at the 4-cell stage (Fig. 1). While the labelling of blastomere nuclei was clearly evident, the label was never associated with nucleoli at this stage. However, a weak incorporation of $\left[{ }^{3} \mathrm{H}\right]$ uridine could be localized at the nucleolar periphery of 4 blastomeres in each of the two embryos that had reached the 6-cell stage (Fig. 2).

Most blastomere nuclei were strongly labelled at the 8-cell and early morula stages (Fig. 3). By contrast to the preceding stages, nucleoli were the most heavily labelled nuclear sites in this type of blastomere ( $\mathrm{Nu}+$ blastomeres) from the 8-cell stage onwards. On the other hand, blastomeres showing relatively low levels of extranucleolar RNA synthesis and nucleoli free of label or only slightly labelled at their periphery ( $\mathrm{Nu}$ - blastomeres) were also present in 8-cell embryos and morulae. The overall numbers of $\mathrm{Nu}+$ and $\mathrm{Nu}-$ blastomeres in the 8-cell embryos and morulae under study are given in Table 1 . Nuclei of $\mathrm{Nu}$ - blastomeres displayed a labelling pattern similar to that observed in 4-cell embryos (Fig. 4). In two cases, this retarded RNA synthetic pattern was revealed in a majority of morula blastomeres without any apparent alteration of the compaction process.

Table 1. Numbers of $\mathrm{Nu}+$ and $\mathrm{Nu}-$ blastomeres in human 8-cell embryos and early morulae

\begin{tabular}{lcccc}
\hline Stage & $\begin{array}{c}\text { No. of } \\
\text { embryos }\end{array}$ & $\begin{array}{c}\text { Total no. of } \\
\text { blastomeres } \\
\text { examined }\end{array}$ & $\begin{array}{c}\text { No. (\%) of } \\
\text { Nu + blastomeres }\end{array}$ & $\begin{array}{c}\text { No. (\%) of } \\
\text { Nu- blastomeres }\end{array}$ \\
\hline 8 -cell & 5 & 38 & $27(71 \%)$ & $11(29 \%)$ \\
Early morula & 5 & 64 & $48(75 \%)$ & $16(25 \%)$ \\
\hline
\end{tabular}



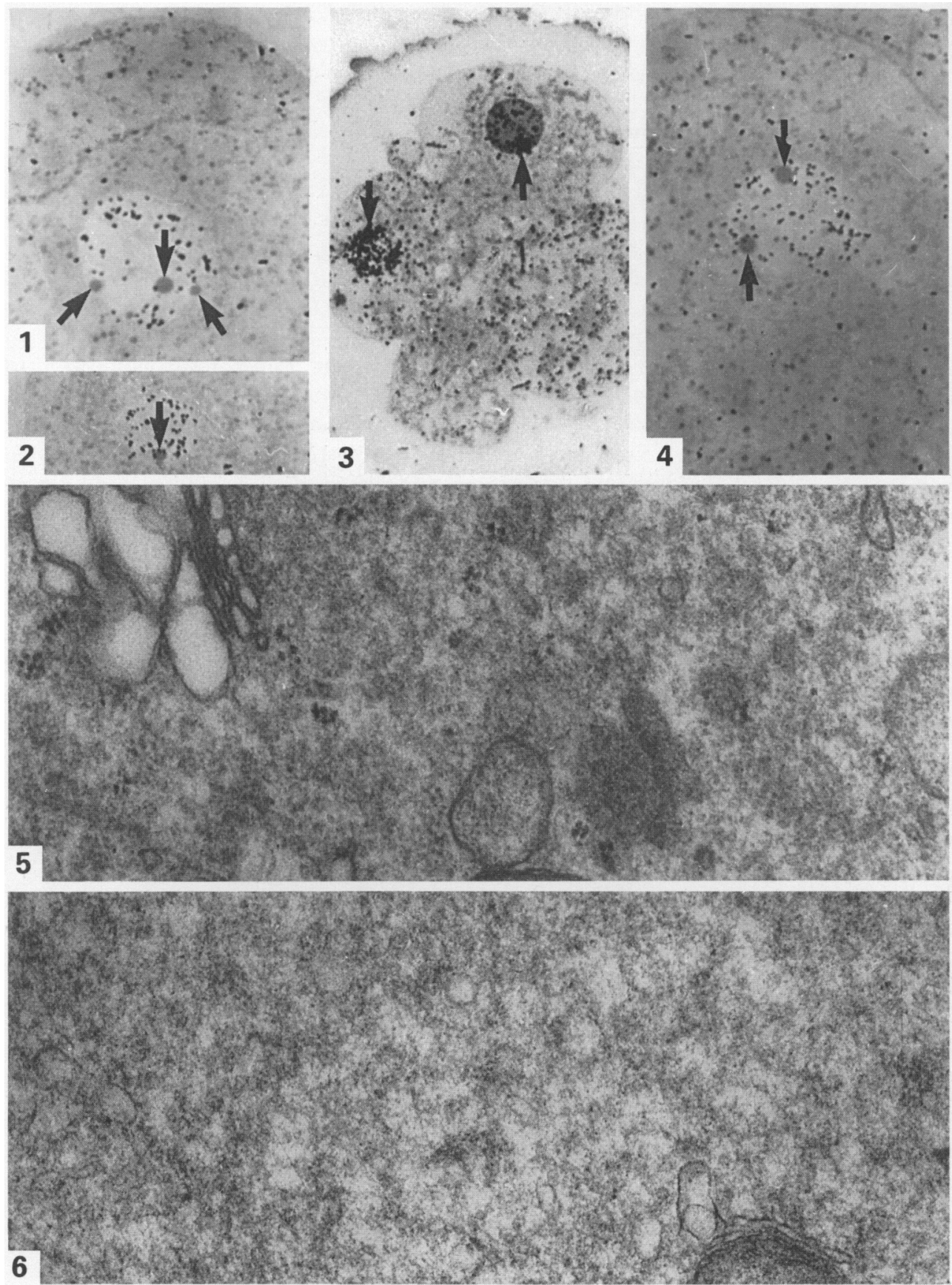

Figs 1-4. Light-microscope autoradiographs of human embryos labelled with $\left[{ }^{3} \mathrm{H}\right]$ uridine.

Fig. 1. Incorporation of $\left[{ }^{3} \mathrm{H}\right]$ uridine is evident in a blastomere nucleus of a 4-cell embryo, but the label is absent from the nucleoli (arrowed). $\times 800$.

Fig. 2. Blastomere nucleus of a 6-cell embryo with a nucleolus (arrowed) labelled at its periphery. Extranucleolar labelling is apparent. $\times 500$. 
Table 2. Content of ribosomes in human embryos at different cleavage stages

\begin{tabular}{|c|c|c|c|}
\hline \multirow[b]{2}{*}{ Stage } & \multicolumn{3}{|c|}{ No. of ribosomes } \\
\hline & $\begin{array}{l}\text { Per } 1-\mu m^{2} \text { section* } \\
\quad(\text { mean } \pm \text { s.d.) }\end{array}$ & Per blastomere* & Per embryo $\dagger$ \\
\hline $\begin{array}{l}2 \text {-cell } \\
(n=4)\end{array}$ & $2.41 \pm 0.36$ & $1.2 \times 10^{7}$ & $2 \cdot 4 \times 10^{7}$ \\
\hline $\begin{array}{l}\text { 4-cell } \\
(n=4)\end{array}$ & $0 \cdot 94 \pm 0 \cdot 17$ & $2.3 \times 10^{6}$ & $9 \cdot 4 \times 10^{6}$ \\
\hline $\begin{array}{l}8 \text {-cell } \\
(n=5)\end{array}$ & $\begin{array}{c}0.80 \pm 0.21 \\
(0.11 \pm 0.04)\end{array}$ & $\begin{array}{l}1.0 \times 10^{6} \\
\left(1.4 \times 10^{5}\right)\end{array}$ & $6.0 \times 10^{6}$ \\
\hline $\begin{array}{l}\text { Early morula } \\
(n=5)\end{array}$ & $\begin{array}{c}1.82 \pm 0.24 \\
(0.08 \pm 0.03)\end{array}$ & $\begin{array}{l}1.4 \times 10^{6} \\
\left(6.1 \times 10^{4}\right)\end{array}$ & $1.4 \times 10^{7}$ \\
\hline
\end{tabular}

\section{Number of ribosomes}

Although no selective staining for ribonucleoproteins was performed, ribosomes were clearly recognizable at the magnification used for their counting (Fig. 5). The results of the morphometric analysis are summarized in Table 2 . The number of ribosomes per $1-\mu \mathrm{m}^{2}$ section area decreases more than twice at the 4-cell stage as compared with the 2-cell stage. This difference between the 2 -cell and 4-cell stages is significant $(P<0.02)$. Only a slight reduction of the mean number of ribosomes was found between the 4-cell and 8-cell stages. The difference in the number of ribosomes per $1-\mu \mathrm{m}^{2}$ section area between the 4-cell enbryos and $\mathrm{Nu}+$ blastomeres of the 8-cell embryos is not statistically significant $(P>0.05)$. When expressed per embryo, however, the decrease in the number of ribosomes in the period between the 4-cell and 8-cell stages is more apparent, owing to the existence of $\mathrm{Nu}$ - blastomeres in 8-cell embryos (Table 2). It is only at the early morula stage that the embryo attains a number of ribosomes nearly equivalent to that at the 2-cell stage.

When counts of ribosomes in 8-cell embryos and early morulae were expressed separately for $\mathrm{Nu}+$ blastomeres (Fig. 5) and for $\mathrm{Nu}$ - blastomeres (Fig. 6), the increase in the concentration of ribosomes per $1-\mu \mathrm{m}^{2}$ section area between the 8-cell and early morula stages was even more apparent in $\mathrm{Nu}+$ blastomeres. In $\mathrm{Nu}$ - blastomeres the concentration of ribosomes was markedly reduced during this period of development (Table 2). When expressed per blastomere, the increase in the ribosomal content in $\mathrm{Nu}+$ blastomeres between the 8-cell and early morula stages was not so

Fig. 3. Strong labelling of blastomere nuclei of an 8-cell embryo. Arrows indicate nucleoli (identified in parallelly cut thin sections) which belong to the most heavily labelled nuclear components. $\times 400$.

Fig. 4. Blastomere nucleus of an early morula showing the delayed pattern of RNA synthesis. Note the low nucleolar synthetic activity (arrows) and the relatively weak extranucleolar labelling. $\times 800$.

Figs 5 and 6. Electron micrographs of parallelly cut thin sections of blastomeres depicted in Fig. 3 to the left (Fig. 5) and in Fig. 4 (Fig. 6). $\times 50000$. 
marked, owing to the decreasing blastomere size. Comparing the ribosomal counts in $\mathrm{Nu}+$ and $\mathrm{Nu}$ - blastomeres (Table 2), the relative proportions of oocyte-inherited and newly produced ribosomes in 8-cell embryos and early morulae can be derived. From these quantitative data it follows that, beginning with the 8-cell stage, the elimination of maternally inherited ribosomes is progressively compensated for by their de-novo production.

The marked decrease in the number of ribosomes in $\mathrm{Nu}$ - blastomeres was not accompanied by any obvious morphological abnormalities; in fact, gross cytoplasmic vacuolization and internal disintegration of mitochondria were observed in only one of the $\mathrm{Nu}$ - blastomeres. Other ultrastructural indications of impaired cellular function, such as the presence of numerous small vacuoles, eccentric position of nuclei, clearing of organelles from the cell periphery, or reduction of microvilli on the cell surface, were occasionally observed both in the $\mathrm{Nu}+$ and $\mathrm{Nu}-$ blastomeres.

\section{Discussion}

The incorporation of $\left[{ }^{3} \mathrm{H}\right]$ uridine into blastomere nuclei of human 4-cell embryos demonstrated by autoradiography clearly indicates that the embryonic genome of the human conceptus begins to be transcribed at least from this developmental stage. It is possible, however, that the embryonic RNA synthesis may be activated even sooner in development after fertilization although $\left[{ }^{3} \mathrm{H}\right]$ uridine incorporation at the 2-cell stage could not be detected. This lack of labelling may be due to the low level of uptake of the radiolabelled uridine into the intraembryonic pool. $\left[{ }^{3} \mathrm{H}\right]$ Uridine incorporation could not be detected in mouse pronuclear embryos although RNA synthesis was already demonstrable at this stage by using tritiated adenosine as precursor (Clegg \& Pikó, 1982). On the other hand, the uptake of radioactive uridine was only three times higher in mouse 4-cell embryos than in 2-cell embryos (Clegg \& Pikó, 1977). It cannot be assumed, however, that the activation of precursor entry follows the same pattern in mouse and human embryos. Moreover, the in-vitro uptake of RNA precursors into the intraembryonic pool may depend on the medium, as demonstrated in the mouse (Woodland \& Graham, 1969). In our study, measurable radioactivity could be detected in the aldehyde fixative after the treatment of human 2-cell embryos previously incubated with $\left[{ }^{3} \mathrm{H}\right]$ uridine (cumulus and corona cells totally removed) and washed free of the unincorporated precursor, suggesting the entry of the precursor into human 2-cell embryos.

Unlike extranucleolar RNA synthesis which is active in human embryos as early as the 4-cell stage, nucleolar RNA synthesis does not start until after the third cleavage division (6-8-cell embryos). It has been previously reported that 'nucleoli' of human 2-4-cell embryos do not contain embryonic DNA and, in fact, are not true nucleoli but merely their precursors (Tesaŕík et al., 1986).

The present results suggest that among different maternally derived RNA species persisting in the early human embryo ribosomal RNA is of particular importance, since the embryo must cover its demand on protein synthesis using exclusively the oocyte-inherited ribosomes throughout the first three cell cycles characterized by nucleolar functional inactivity. The quantitative changes in the ribosomal content during cleavage of the human embryo, as described in this study, are in accordance with the notion that de-novo formation of ribosomes begins concomittantly with the activation of nucleolar rRNA synthesis. A decrease in the number of ribosomes, similar to that observed in this study between the 2-cell and 4-cell stages, has been reported to take place between the pronuclear and 2-cell stages in the mouse embryo (Piko \& Clegg, 1982) in which rRNA synthesis begins at the 2-cell stage (Clegg \& Pikó, 1982). This reduction of the ribosomal population can be easily explained by the elimination of aged structures in the absence of the production of new ones.

The relatively low numbers of ribosomes in human 2-cell embryos $(<10 \%$ less when expressed per unit section area and about $50 \%$ lower when expressed per embryo), compared with 2-cell conceptuses of the mouse (Pikó \& Clegg, 1982; Trávník \& Zimová, 1984), are unusual, suggesting that 
the human zygote inherits a significantly smaller amount of ribosomes from the oocyte than does that of the mouse. This finding is surprising in view of the delayed production of new ribosomes by the human embryo. Very low numbers of ribosomes have been reported for early cleavage stages of human embryos developing in vivo (Pereda \& Croxatto, 1978) and in vitro (Sundström, Nilsson \& Liedholm, 1981; Sathananthan, Wood \& Leeton, 1982), although quantitative evaluations were not performed. We cannot confirm the observation that ribosomes occur exclusively as monosomes in early human cleavage stages (Sundström et al., 1981; Sathananthan et al., 1982); most ribosomes observed in the present study appeared to be organized in polysomes (Fig. 5).

On the basis of the methodology employed, it is not possible to decide whether the RNA transcripts newly synthesized in human 4-cell embryos are immediately used for translation or stored for later utilization. In any case, if there is any translation of the newly synthesized extranucleolar (presumably at least in part messenger) RNA in human 4-cell embryos, it is evidently fully dependent on the maternally inherited supply of ribosomes. The concentration of ribosomes in the preovulatory human oocyte may then be an important factor of its developmental potential. The resumption of nucleolar synthetic activity during the 4 th cell cycle of human embryos seems to be of vital importance for a given blastomere as the extremely low numbers of ribosomes in $\mathrm{Nu}-$ blastomeres of human 8-16-cell embryos seem to be hardly compatible even with assuring the basic cellular functions, such as renewal of cell organelles and enzymic systems necessary for the maintenance of cell integrity.

From an analysis of implantation rates and the incidence of multiple implantations achieved by four major IVF groups (Rogers, Milne \& Trounson, 1986), it is evident that the probability that a human embryo grown in vitro is viable ranges between 0.21 and 0.32 . It is tempting to speculate that $\mathrm{Nu}$ - blastomeres of human 8-cell embryos and early morulae may be those going to die. The proportion of $\mathrm{Nu}+$ and $\mathrm{Nu}$ - blastomeres may thus play a decisive role in the developmental potential of a given embryo. The seemingly normal ultrastructural appearance of such blastomeres, which also develop the competence to participate in the compaction process, is therefore surprising. Because many apparently normal human morulae fail to develop further to the blastocyst stage (unpublished observation), it appears that the developmental defect manifests itself later, probably during blastulation. Further comparison of $\mathrm{Nu}+$ and $\mathrm{Nu}-$ blastomeres may give a new dimension to the ultrastructural investigation of human embryos.

\section{References}

Clegg, K.B. \& Pikó, L. (1977) Size and specific activity of the UTP pool and overall rates of RNA synthesis in early mouse embryos. Devl Biol. 58, 76-95.

Clegg, K.B. \& Pikó, L. (1982) RNA synthesis and cytoplasmic polyadenylation in the one-cell mouse embryo. Nature, Lond. 295, 342-345.

Clegg, K.B. \& Pikó, L. (1983) Quantitative aspects of RNA synthesis and polyadenylation in 1-cell and 2-cell mouse embryos. J. Embryol. exp. Morph. 74, $169-182$.

Cotton, R.W., Manes, C.\& Hamkalo, B.A. (1980) Electron microscopic analysis of RNA transcription in preimplantation rabbit embryos. Chromosoma 79, $169-178$.

Epstein, C.J. (1975) Gene expression and macromolecular synthesis during preimplantation embryonic development. Biol. Reprod. 12, 82-105.

Flach, G., Johnson, M.H., Braude, P.R., Taylor, R.A.S. \& Bolton, V.N. (1982) The transition from maternal to embryonic control in the 2-cell mouse embryo. The EMBO Journal 1, 681-686.

Johnson, M.H. (1981) The molecular and cellular basis of preimplantation mouse development. Biol. Rev. 56, 463-498.

Knowland, J. \& Graham, C. (1972) RNA synthesis at the two-cell stage of mouse development. J. Embryol. exp. Morph. 27, 167-176.

Loud, A.V. (1968) A quantitative stereological description of the ultrastructure of normal rat liver parenchymal cells. J. Cell. Biol. 37, 27-46.

Magnuson, T. \& Epstein, C.J. (1981) Genetic control of very early mammalian development. Biol. Rev. 56, $369-408$.

Manes, C. (1971) Nucleic acid synthesis in preimplantation rabbit embryos. II. Delayed synthesis of ribosomal RNA. J. exp. Zool. 176, 87-96.

McDonald, K. (1984) Osmium ferricyanide fixation improves microfilament preservation and membrane 
visualization in a variety of animal cell types. J. Sathananthan, A.H., Wood, C. \& Leeton, J.F. (1982) Ultrastruct. Res. 86, 107-118.

Moanneron, A. \& Moulé, Y. (1969) Critical evaluation of specificity in electron microscopical radioautography in animal tissues. Expl Cell Res. 56, 179-193.

Pereda, J. \& Croxatto, H.B. (1978) Ultrastructure of a seven-cell human embryo. Biol. Reprod. 18, 481-489.

Pikó, L. \& Clegg, K.B. (1982) Quantitative changes in total RNA, total poly(A), and ribosomes in early mouse embryos. Devl Biol. 89, 362-378.

Plachot, M., Mandelbaum, J., Cohen, J.J., Debache, C., Pigeau, F. \& Junca, A.-M. (1985) Sequential use of clomiphene citrate, human menopausal gonadotropin, and human chorionic gonadotropin in human in vitro fertilization. I. Follicular growth and oocyte suitability. Fert. Steril. 43, 255-262.

Rogers, P.A.W., Milne, B.J. \& Trounson, A.O. (1986) A model to show human uterine receptivity and embryo viability following ovarian stimulation for in vitro fertilization. $J$. in Vitro Fert. Embryo Transfer 3, 93-98.

Ultrastructural evaluation of $8-16$ cell human embryos cultured in vitro. Micron 13, 193-203.

Sundström, P., Nilsson, O. \& Liedholm, P. (1981) Cleavage rate and morphology of early human embryos obtained after artificial fertilization and culture. Acta obstet. gynec. scand. 60, 109-1 20.

Tesař́í, J., Kopečný, V., Plachot, M., Mandelbaum, J., Da Lage, C. \& Fléchon, J.-E. (1986) Nucleologenesis in the human embryo developing in vitro; ultrastructural and autoradiographic analysis. Devl Biol. 115, 193-203.

Trávník, P. \& Zimová, M. (1984) Quantitative representation of ribosomes during cleavage of the mouse ovum. Folia morph., Prague 32, 9-15.

Woodland, H.R. \& Graham, C.F. (1969) RNA synthesis during early development of the mouse. Nature, Lond. 221, 327-332.

Received 7 February 1986 